\title{
Effect of Customer Satisfaction, Switching Cost and Referent Network Size on Customer Loyalty in Chinese Mobile Communication Service
}

\author{
Fengjiao Zhang \\ Management School \\ Wuhan University of Science and Technology \\ Wuhan, China \\ 1175843674@qq.com
}

\author{
Hong Zhang \\ Management School \\ Wuhan University of Science and Technology \\ Wuhan, China \\ savagegardenzh@163.com
}

\begin{abstract}
As the mobile communication service industry becomes more and more competitive and consumers tend to become increasing demanding, protecting the present customer base appears to be the focus of marketing strategy. In order to give advice for mobile communication service industry to improve the customer loyalty, this study constructs the conceptual model, through the empirical research method to examine the effects of customer satisfaction, switching cost and referent network size on customer loyalty in the context of mobile communication service. The results show that satisfaction and referent network size positively affect customer loyalty. And the satisfaction is found to be the best predictor of customer loyalty. This study firstly examines the effects of referent network on customer loyalty and the interactions between factors affecting customer loyalty. This is of great significance to both theoretical and practical research.
\end{abstract}

Keywords-satisfaction; switching cost; referent network size; mobile communication; loyalty

\section{INTRODUCTION}

The Chinese mobile communication service market has become increasingly competitive as a consequence of the removal of monopoly rights. With the intense challenges to attract new customers, mobile service providers continually initiate promotion activities to acquire, retain and increase their subscriber base, thereby leading to a high rate of customer attrition. According to the report from the marketing department of China Mobile, the customer churn rate range from 5.1 percent to 8.1 percent in the past one year on account of more fierce competition on the one hand and more demanding customers on the other hand. Thus, achieving and maintaining a competitive market share is becoming increasingly difficult.

Under such a situation, employing defensive strategy of protecting the present customer base appears to be a meaningful marketing strategy for mobile service providers in order to survive and succeed in this competitive mobile communication market. Various researchers also advocated that developing and maintaining customer loyalty is the key to the survival and growth of service firms. [1-3]. Mobile service providers have realized that maintaining a loyal customer base not only create long-term relationships with customers but also lead to competitive advantage $[1,4]$.

Earlier studies suggest that customer loyalty provides the foundation for a company's sustained development, and that developing and increasing customer loyalty is a crucial factor in companies' growth and performance [5, 6]. However, in China, only limited studies have been conducted on the antecedences of customer loyalty in the context of mobile communication service. Further, to the best of our knowledge, there are no empirical studies examining the theory that referent network size may increase customer loyalty and examining the interactions between factors affecting customer loyalty.

In this regard, the objective of this study is to (1) examine the effects of customer satisfaction, switching cost, and referent network size on customer loyalty, (2) explore the interactive effect between switching cost and referent network size, and (3) discuss the strategic implications for mobile service providers attempting to enhance their loyal customer base in Chinese mobile communication service industry.

\section{CONCEPTUAL FRAMEWORK}

\section{A. Customer Loyalty}

Dick and Basu classified the customer loyalty into cognitive loyalty, emotional loyalty, intentional loyalty and behavioral loyalty, and the first three kinds of loyalties are combined into one, namely, attitudinal loyalty[7, 8]. Thus, customer loyalty is understood as a combination of customers' favorable attitude and the behavior of repurchase[7].

Customer loyalty contributes to performance and future growth of the company. Specially, when the market experiences slow growth and fierce competition, a defensive strategy of retaining existing customers is more important than an aggressive one of expanding the overall market share [1].

In the case of Chinese mobile communication service, customer loyalty is particularly significant, given the high customer loss rate. Further, the introduction of various mobile 
services is likely to increase customer churn, making customer loyalty more crucial than ever[6].

\section{B. Customer Satisfaction}

Customer satisfaction reflects a summary psychological state resulting from a product/service acquisition and/or consumption experience[9]. In many studies, customer satisfaction has been advocated as an easier and reliable source of profits by preventing customers from defecting. Fornell concluded that high level of customer satisfaction should produce favorable word of mouth, which in turn has a positive effect on market share[1]. Further, a consistently high satisfaction level may generate a long-run reputation effect, as well as improve customer loyalty by reducing customers' price sensitivity[10]. Thus, we propose that

H1 Customer satisfaction has a positive effect on customer loyalty.

\section{Switching Cost}

Fornell defined switching cost as a combination of search cost, transaction cost, learning cost, loyal customer discounts, customer habit, emotional cost, and cognitive effort[1]. In the context of mobile communication service, switching cost include monetary cost of purchasing new number, learning cost, time and effort of informing all relative people. It is obvious that the higher the switching cost is, the more difficult for customers to switch from the present service provider to the competitors. Accordingly, developing switching cost is an important strategy advocated to increase loyalty on account of discouraging customer switching[7]. Thus, we propose that

H2 Switching cost has a positive effect on customer loyalty.

\section{Referent Network Size}

Referent network size refers to the number of customers in a given network, which depends on the number of people in the user's social circle who also are users of the service provider[11]. Communication within the given network would be more convenient and economical. According to the previous study, referent network size has a significant effect on consumer loyalty via increasing perceived usefulness and satisfaction[12]. Further, the greater referent network size will produce greater communication and psychological cost when switching from the present service provider to the competitor. Thus, we propose that

H3 Referent network size has a positive effect on customer loyalty.

H4 Referent network size has a positive effect on switching cost.

A research model is shown in Fig. 1 which theorizes the relationship between satisfaction, switching cost, referent network size, and customer loyalty.

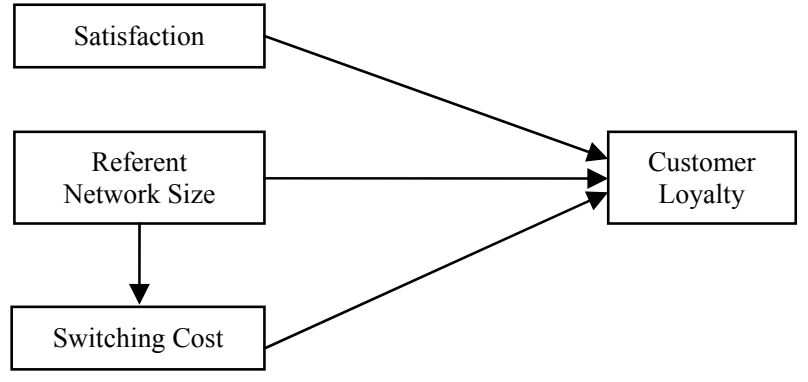

Fig. 1. Research model.

\section{RESEARCH METHOD}

For the examining of research model, the survey items were derived from the previous literature and were modified to fit the context of mobile communication service. For the survey items of satisfaction, we employed three items which measured the overall customer satisfaction and conformity with pre-purchase expectations of the customers. The questionnaire items for referent network size were adapted from the previous study. According to the definition of switching cost, four items were developed based on previous studies. Perceived monetary cost, learning cost, uncertainty cost, time and effort were considered. Finally, in order to measure customer loyalty, the study adopted the three items adapted from Zeithaml, Berry, and Parasuraman.

To improve the content validity of measurement, the questionnaires were first finished by a panel of 10 managers of China Mobile, the largest mobile service provider in China. Based on the feedback from the managers, the questionnaire was revised to assure the suitability and readability of items.

We conducted a face-to-face data survey in a Mobile Service Hall. In total, 491 responses were returned a week later, of which 40 incomplete ones were dropped and the remaining 451 were used for subsequent analyses. The demographic characteristics of the responses are presented in Table I

TABLE I. DEMOGRAPHICS OF THE RESPONDENTS

\begin{tabular}{|c|c|c|c|}
\hline Demographics & Category & Frequency & $\%$ \\
\hline \multirow{2}{*}{ Gender } & Male & 244 & 54 \\
\hline & Female & 207 & 46 \\
\hline \multirow{6}{*}{ Age } & $\sim 18$ & 8 & 2 \\
\hline & $18 \sim 24$ & 316 & 70 \\
\hline & $25 \sim 30$ & 85 & 19 \\
\hline & $31 \sim 35$ & 24 & 5 \\
\hline & $36 \sim 40$ & 5 & 1 \\
\hline & $40 \sim$ & 13 & 3 \\
\hline \multirow{4}{*}{ Education Level } & Secondary & 45 & 10 \\
\hline & College & 82 & 18 \\
\hline & University & 211 & 47 \\
\hline & Master & 110 & 25 \\
\hline \multirow{6}{*}{ Occupation } & Student & 293 & 64 \\
\hline & General employee & 106 & 24 \\
\hline & Manager & 20 & 5 \\
\hline & Government official & 4 & 1 \\
\hline & Teacher & 10 & 2 \\
\hline & Other & 16 & 4 \\
\hline
\end{tabular}




\begin{tabular}{|c|c|c|c|}
\hline \multicolumn{4}{|c|}{ Cont. to TABLE I } \\
\hline \multirow{6}{*}{ Income per month $(¥)$} & No & 207 & 46 \\
\hline & $\sim 1000$ & 61 & 14 \\
\hline & $1000 \sim 2999$ & 120 & 27 \\
\hline & $3000 \sim 4999$ & 37 & 8 \\
\hline & 5000 6999 & 17 & 4 \\
\hline & $\overline{7000 \sim}$ & 4 & 1 \\
\hline \multirow{4}{*}{$\begin{array}{l}\text { Work Experience } \\
\text { (year) }\end{array}$} & $0 \sim 1$ & 292 & 65 \\
\hline & $1 \sim 3$ & 71 & 16 \\
\hline & $3 \sim 5$ & 35 & 8 \\
\hline & $5 \sim$ & 49 & 11 \\
\hline \multirow{4}{*}{$\begin{array}{ll}\text { Average } & \text { mobile } \\
\text { phone fee(¥) } & \end{array}$} & $\sim 30$ & 46 & 10 \\
\hline & $30 \sim 99$ & 308 & 69 \\
\hline & $100 \sim 199$ & 78 & 17 \\
\hline & $200 \sim$ & 16 & 4 \\
\hline \multirow{4}{*}{ Customer Type } & Shenzhouxing & 79 & 18.5 \\
\hline & M-zone & 329 & 72 \\
\hline & GSM & 39 & 9 \\
\hline & Group user & 3 & 0.5 \\
\hline
\end{tabular}

IV. RESULTS

\section{A. Measurement Model}

To verify the reliability of the measurement items, the coefficient of Cronbach Alpha is computed and the results are shown in Table II. When alpha value reaches 0.70 , it is regarded to be reliable. All alpha values range from 0.767 to 0.942 , exhibiting a satisfactory level of reliability.

\section{TABLE II. CRONBACH ALPHA COEFFICIENT}

\begin{tabular}{|c|c|c|}
\hline Construct & $\begin{array}{c}\text { Number of } \\
\text { Items }\end{array}$ & Cronbach Alpha \\
\hline Satisfaction & 3 & 0.942 \\
\hline Switching Cost & 4 & 0.767 \\
\hline Referent Network Size & 3 & 0.900 \\
\hline Customer Loyalty & 3 & 0.893 \\
\hline
\end{tabular}

Next, convergent and discriminant validity were tested with AMOS17.0 and SPSS 16.0. The values of average variance extract (AVE) for satisfaction, referent network size and customer loyalty constructs are $0.847,0.766$ and 0.726 respectively, demonstrating a high level of convergent validity. In addition, although the AVE for switching cost only reaches 0.508 , it still is above the suggested threshold of $0.5[13]$. Further, the values of composite reliability for the four constructs range from 0.750 to 0.943 , confirming a good reliability $[14,15]$.

Finally, the square root of the AVE for each construct is greater than the variance shared between the construct and other constructs, which is shown in Table III and verifies the discriminant validity.

TABLE III. RESULTS OF DISCRIMINANT VALIDITY

\begin{tabular}{|l|c|c|c|c|}
\hline & Satisfaction & $\begin{array}{c}\text { Referent } \\
\text { Network } \\
\text { Size }\end{array}$ & $\begin{array}{c}\text { Switching } \\
\text { Cost }\end{array}$ & $\begin{array}{c}\text { Consumer } \\
\text { Loyalty }\end{array}$ \\
\hline Satisfaction & 0.920 & 0.875 & & \\
\hline $\begin{array}{l}\text { Referent } \\
\text { Network } \\
\text { Size }\end{array}$ & 0.478 & 0.327 & 0.713 & \\
\hline $\begin{array}{l}\text { Switching } \\
\text { Cost }\end{array}$ & 0.247 & 0.457 & 0.238 & 0.852 \\
\hline $\begin{array}{l}\text { Consumer } \\
\text { Loyalty }\end{array}$ & 0.770 & & & \\
\hline
\end{tabular}

\section{B. Structural Model}

Almost all proposed hypotheses are supported. As predicted, satisfaction has a strong positive effect on loyalty (path=0.738, $\mathrm{p}<0.001$ ), supporting H1. Then, referent network size shows a significant relationship with customer loyalty (path $=0.134, p<0.001$ ), thus in support of H3. Further, we find referent network size has a positive effect on switching cost (path $=0.328, \mathrm{p}<0.001$ ) and $\mathrm{H} 4$ is supported. Interesting, the effect of switching cost on customer loyalty was found nonsignificant, thereby not supporting $\mathrm{H} 2$. Upon reflection, the result is meaningful. The reason may be the fact that in Chinese mobile communication service industry, the barrier preventing customers switching from the present service provider to the competitor is relatively weak.

The result also provides various indicators to reveal the fit goodness of the proposed model and the sample data. The values of fit and the recommended standard values are depicted in Table IV. All values indicate an acceptable fit between the model and the sample data.

TABLE IV. MODEL FIT INDICES

\begin{tabular}{|c|c|c|}
\hline Fit Index & Model Value & $\begin{array}{c}\text { Recommended } \\
\text { value }\end{array}$ \\
\hline GFI & 0.949 & $>0.9$ \\
\hline RMSEA & 0.067 & $<0.1$ \\
\hline NFI & 0.963 & $>0.9$ \\
\hline CFI & 0.975 & $>0.9$ \\
\hline TLI & 0.966 & $>0.9$ \\
\hline
\end{tabular}

\section{DISCUSSION}

Several implications are drawn from our study for the service providers in Chinese mobile communication industry. First, it will continue to be important for service providers to improve customer satisfaction. In our study, satisfaction is found to be the best predictor of customer loyalty. It is believed that high level of customer satisfaction will lead to favorable word of mouth, thereby producing a positive effect on market share[1]. Fornell concluded that satisfied customers are an asset to the firm[1]. Thus, whenever, improving customer satisfaction should be an important part of the marketing strategy.

Second, the study confirms the influence of market share in mobile communication service context because of the significant effect of referent network size on customer loyalty. The great market share can increase perceived referent network size, thus improving customer loyalty. Accordingly, service providers still should compete in increasing market share and capturing market share via an offense strategy.

Finally, our study suggests that service providers should not set too much switching barriers, which means nothing for customers who intend to switch. Further, high switching cost may make customers averse, therefore reducing the satisfaction level.

\section{CONCLUSION}

The main purpose of this study is to test the effects of satisfaction, referent network size, and switching cost on 
customer loyalty, as well as the interactive effect between referent network size and switching cost on the context of mobile communication service. The results show that the customer satisfaction is the most significant predictor of the customer loyalty and referent network size positively affects the customer loyalty. Further, referent network size has a positive effect on switching cost.

This study provides meaning implications for mobile service providers. Service providers should improve customer satisfaction and referent network size to enhance customer loyalty. Thus, it may be important for Chinese mobile service providers to implement both an offense strategy of increasing referent network size and a defense strategy of improving customer satisfaction.

\section{ACKNOWLEDGMENT}

This work was supported by the grants from the NSFC (71602152) and the Science and Technology Program in Hubei: Specialised Project for Technical Innovation (2017ADC111).

\section{REFERENCES}

[1] C. Fornell, "A national customer satisfaction barometer: the swedish experience," The Journal of Marketing, vol. 56, pp. 6-21, 1992.

[2] F. Lai, M. Griffin, and B. J. Babin, "How quality, value, image, and satisfaction create loyalty at a Chinese telecom," Journal of Business Research, vol. 62, pp. 980-986, 2009.

[3] A. Seth, K. Momaya, and H. M. Gupta, "An exploratory investigation of customer loyalty and retention in cellular mobile communication," Journal of Services Research, pp. 173-185, 2005.

[4] S. K. Chadha and D. Kapoor, "Effect of switching cost, service quality and customer satisfaction on customer loyalty of cellular service providers in indian market," in ICFAI Journal of Marketing Management vol. 8, ed: IUP Publications, 2009, pp. 23-37.

[5] M. Lee and L. F. Cunningham, "A cost/benefit approach to understanding service loyalty," Journal of Services Marketing, vol. B, pp. 15(2), 113-130, 2001.

[6] M.-K. Kim, M.-C. Park, and D.-H. Jeong, "The effects of customer satisfaction and switching barrier on customer loyalty in Korean mobile telecommunication services," in Telecommunications Policy vol. 28, B, Ed., ed, 2004, p. 145.

[7] A. S. Dick and K. Basu, "Customer loyalty: toward an integrated conceptual framework," in Journal of the Academy of Marketing Science vol. 22, A*, Ed., ed: Springer Science \& Business Media B.V., 1994, pp. 99-113.

[8] R. L. Oliver, "Whence consumer loyalty?," The Journal of Marketing, vol. 63, pp. 33-44, 1999.

[9] R. L. Oliver, "Satisfaction: a behavioral perspective on the consumer," Irwin McGraw-Hill, Boston 1997.

[10] E. W. Anderson and M. W. Sullivan, "The antecedents and consequences of customer satisfaction for firms," Marketing Science, vol. 12, pp. 125-143, 1993.

[11] L. Chieh-Peng and A. Bhattacherjee, "Elucidating individual intention to use interactive information technologies: the role of network externalities," in International Journal of Electronic Commerce vol. 13, A, Ed., ed: M.E. Sharpe Inc., 2008, pp. 85-108.

[12] T. Zhou and Y. Lu, "Examining mobile instant messaging user loyalty from the perspectives of network externalities and flow experience," in Computers in Human Behavior vol. 27, ed, 2011, pp. 883-889.

[13] C. Fornell and D. F. Larcker, "Evaluating structural equation models with unobservable variables and measurement error," in Journal of Marketing Research (JMR) vol. 18, ed: American Marketing Association, 1981, pp. 39-50.

[14] D. Straub, M.-C. Boudreau, and D. Gefen, "Validation guidelines for is positivist research," in Communications of AIS vol. 2004, ed: Association for Information Systems, 2004, pp. 380-427.

[15] J. Joseph F. Hair, R. E. Anderson, R. L. Tatham, and W. C. Black, "Multivariate data analysis (5th ed.): with readings," Englewood Cliffs, NJ: Prentice Hall, 1998. 